Joanna Markowska

\title{
THE ORIGINS OF THE PLITVICE LAKES (CROATIA)
}

\begin{abstract}
The question of the origin of the Plitvice Lakes, situated in the Dynarics Mountains, in central Croatia is still unexplained. Not so many place in a literature is dedicated to this issue. It is said that the Plitvice Lakes are of tectonic or karst origin. In the article the complicated origin of the lakes is shown. To define their origin the author proposes the term "tectonic - barriered". As a result of tectonical movements which occured on the researched area, many tectonic faults were formed. At the bottom of the lakes barriers of sedra - rock of biogenic origin started to grow. The process of sedra creating has been lasting till today and as a result a very complicated, permanently transformed lakes system has formed. At present, below the lowest located lake of the Plitvice Lakes new lakes appear, which demonstrate about existing and growing submarine barriers.
\end{abstract}

Key words: origin, Plitvice, lakes, tectonic, barriers, sedra.

Not much has been written in scientific literature about the origins of the Plitvice Lakes, situated in the Dinaric Alps in central Croatia. The lakes are regarded as being of tectonic or karst origins. In this article a complex genesis of the Plitvice Lakes is presented; the term "tectonic-barrier origins" is suggested.

The Plitvice Lakes are situated in a valley between the Velebit and the Plješevica mountain ranges in central Croatia. Because of their unusual natural qualities, in 1949 the lakes together with the surrounding forest became a natural preserve within the oldest and also the largest national park of Croatia, called "Plitvička jezera" ("Plitvice Lakes"). The surface of the park is currently equal to 294.82 square $\mathrm{km}$.

The lakes are situated in the central part of the park, in the longitudinally running valley of the Korana River. The water table of the highestsituated lake, Prošćansko, is at 636 metres above sea level, while that of the lowest-situated one, Novakovića Brod, at 503 metres above sea level. The remaining 14 lakes form a sequence of steps between the two. The distance between the two extreme points of the system equals $12 \mathrm{~km}$ with a drop of 133 metres.

The bedrock of the region under investigation is built of Mesozoic rocks. Dolomite, whose deposits are estimated to be equal to $400-600 \mathrm{~m}$, comes from the upper Triassic. Limestone and dolomite were created in the Jurassic, while during the lower Cretaceous limestone, with thickness estimated to be 
800-1000 m, was formed (Polšak, 1974). Subsequently, during the Laramide phase of the Alpine orogeny, the deposits of rocks became folded and uplifted; as a result, their thick sequence became disturbed by numerous tectonic faults. The main fault running through the park has the NW-SE direction, coinciding with the direction of the main mountain ranges and faults of the Dinaric Alps. This fault played an important role in the formation of the park's relief, since it divides the impermeable dolomite of which its southwestern part is built from the permeable limestone in the northeastern part. Such geological structure allowed for the accumulation of water in the region built of dolomite; this, in turn, made possible the formation of relatively large lake basins. The lakes situated in the northeastern part of the park, built of limestone, have relatively small surface (max. 2.92 hectares, Lake Milanovac) and a very weakly developed coastline. They do not form independent basins, but are fragments of the riverbed.

Until now, it was believed that the Plitvice Lakes are of tectonic origins. According to Petrik (1958) their formation was initiated by tectonic movements occurring during the Laramie phase of the Alpine orogeny, which caused the lowering of the Korana riverbed. The hydrologists' definition states that tectonic lakes "owe their existence to the crustal movements and fill up tectonic depressions" (Bajkiewicz-Grabowska, Mikulski, 1996), for example the lakes of the African Rift Valley or Lake Baikal. From the geological map it follows that the Plitvice Lakes do not lay in a tectonic trough. Faults are situated across the lake basins, and the distances between them range from around 15 meters to a few hundred meters. The lakes are much shallower than any known tectonic lakes: the maximal depth is equal to $46 \mathrm{~m}$ (Lake Kozjak).

Klimaszewski (2003), does not write anything about the tectonic origins or the role of vegetation in the formation of the Plitvice Lakes. He explains their origins by chemical processes: "As a result of the sudden decrease of the $\mathrm{CO}_{2}$ contents in the spring and river waters, saturated with calcium carbonate dish-shaped depressions, and spring tufa are formed near the springs, and thresholds, cascades and calc-sinter depression, in the river valleys (e.g., the Plitvice Lakes in the Korana River valley in the Dinaric Alps or in valleys near Cracow, Poland)". The process of precipitation of calcium carbonate played a huge role in the formation of the Plitvice Lakes; it is not, however, the only process which contributed to their formation.

While searching for the answer to the question about the origins of the Plitvice Lakes, the theory of karst origins has been discarded. This theory holds that the lakes fill out "sinkholes or basins in the regions built of limestone or gypsum rocks" (Bajkiewicz-Grabowska, Mikulski, 1996). The system under investigation does not, however, fill out chaotically distributed karst sinkholes, but forms a sequence in the Korana River valley, in which barriers reaching the height from a few tens of centimetres to around 15 meters divide the consecutive lakes.

These barriers played a fundamental role in the creation of the lakes. They began to form in the Holocene, when the climate became warmer. The 


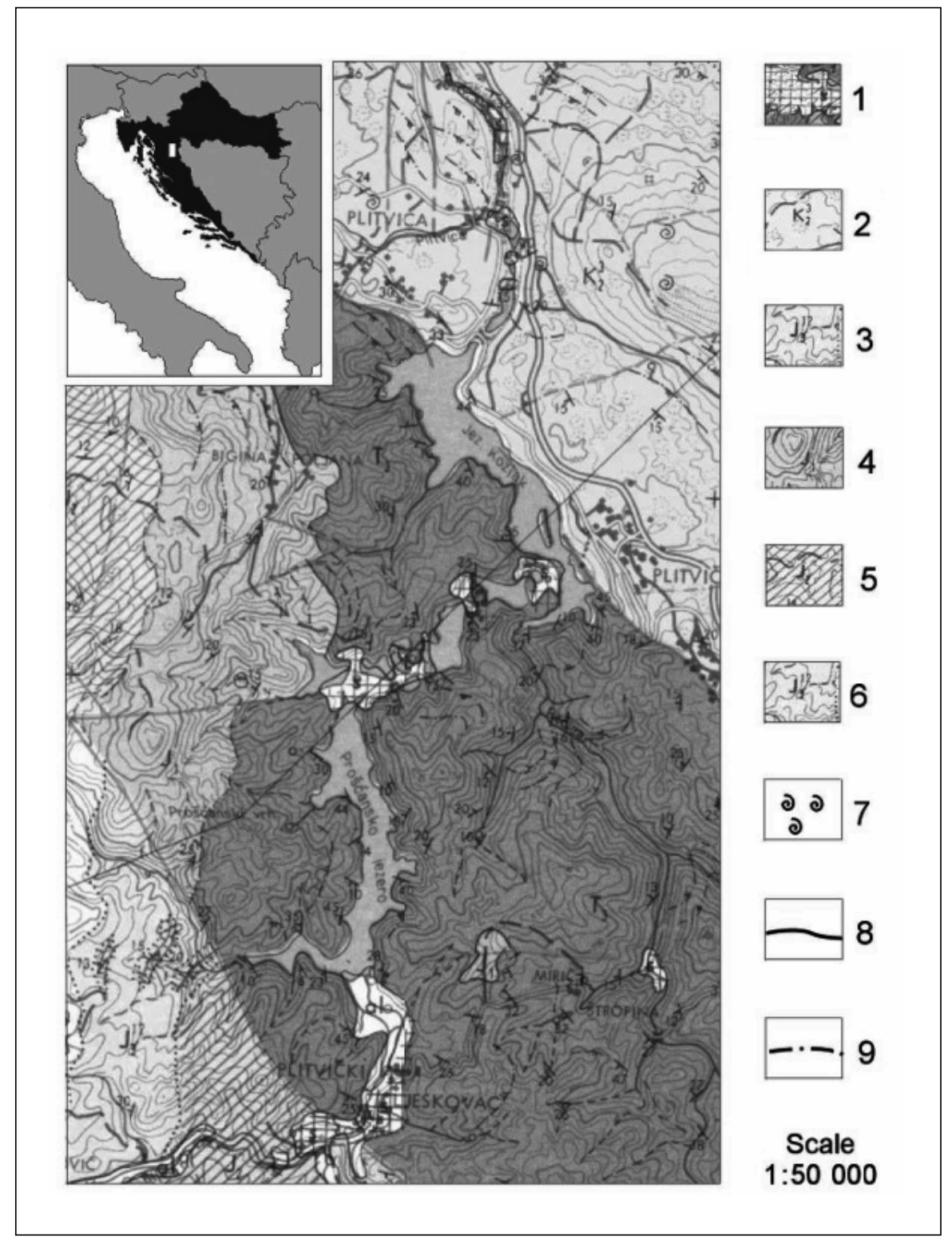

Fig. 1. Localisation and geological map of the Plitvice Lakes region.

1 - Quaternary travertine; 2 - Thickly stratified Cretaceous limestone; 3 - Stratified Jurassic limestone with Oxford dolomite intercalations; 4 - Stratified Jurassic limestone with Doger dolomite intercalations; 5 - Upper part: dolomite, lower part: Jurassic limestone; 6 - Stratified Triassic dolomite; 7 - Localisations of macrofauna; 8 - Faults; 9 -Approximate localisation of faults.

Source: Geological Map of the National Park "Plitvice Lakes" 1:50 000. Cartographic Laboratory, Zagreb, 1971. 


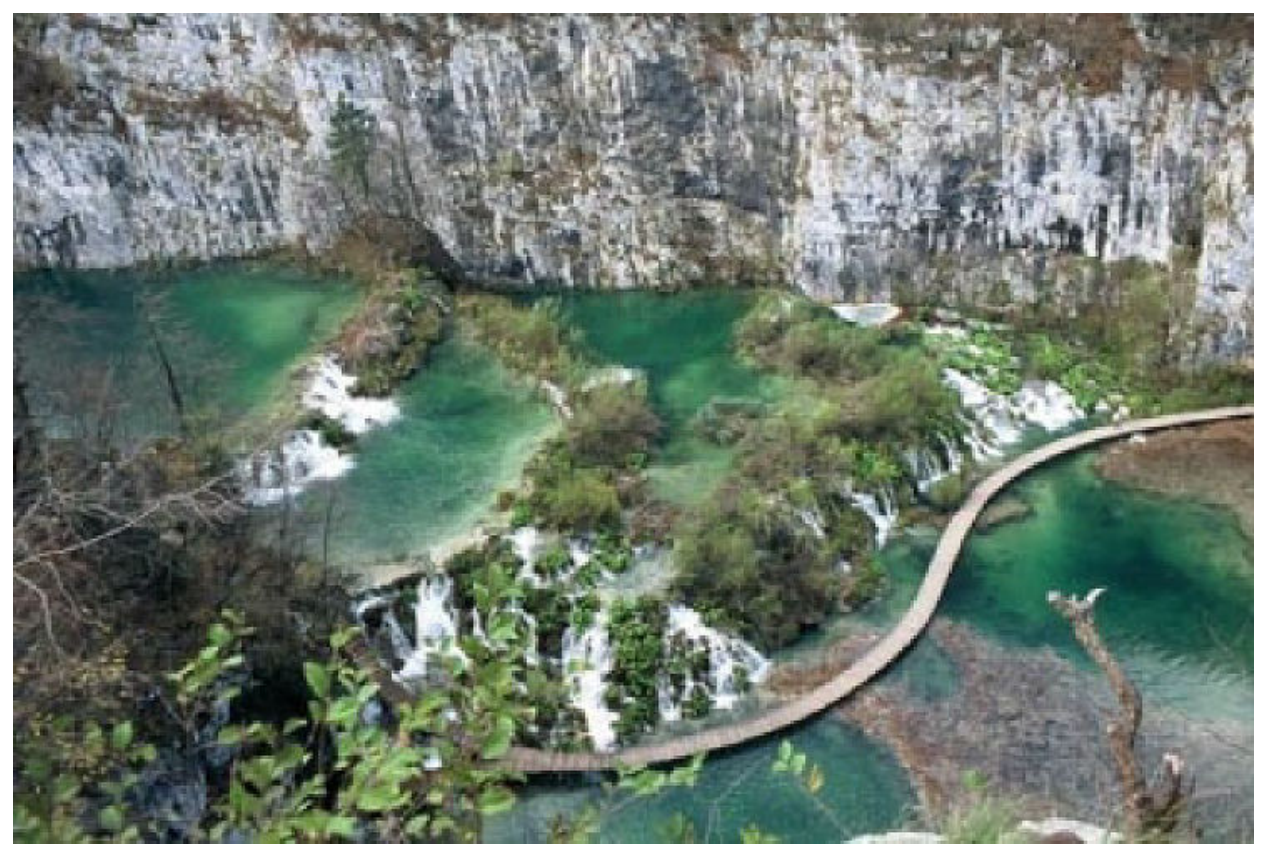

Fig. 2. An example of barriers separating reservoirs. On the left Lake Kaluderovac, on the right Lake Novakovića Brod (Photo J. Markowska).

analysis of the geological map and field observations indicate that the barriers were formed on tectonic faults, which is related to the disturbance of the $\mathrm{CO}_{2}$ equilibrium in such places, resulting from the sudden release of $\mathrm{CO}_{2}$ from under rock layers lying above. Karst waters are saturated with calcium carbonate, which is precipitated from water and forms underwater barriers. Growing by a few millimetres each year, the barriers eventually emerge above the water surface where mosses start growing on them. The moss species occurring in the Plitvice Lakes are Cratoneuronum Commutatum and Bryum Pseudotriquetum (Pevalek, 1958). Bacteria living on the moss extract calcium carbonate dissolved in the water and include it in their structure; as a result, the moss petrifies and turns into rock. Rock created this way is called tufa (sedra). Such biogenic rocks are particularly characteristic for the Plitvice region, but rare elsewhere in the world. Petrified fragments of moss can be seen in the structure of the rocks. Tufa plays a great relief-forming role, since it causes the division of lakes into smaller reservoirs.

During ten to twenty thousand years, in the latitudinally running faults some ten to twenty barriers have been created; they divided the Korana riverbed and closed from the north the lake basins created this way.

Human activity played a certain role in the creation and disappearance of the individual lakes. For mills and sawmills, which were being built in the $18^{\text {th }}$ and $19^{\text {th }}$ centuries, canals were dug to change the course of water; the area was drained. As a result, some ten to twenty lakes have disappeared. 


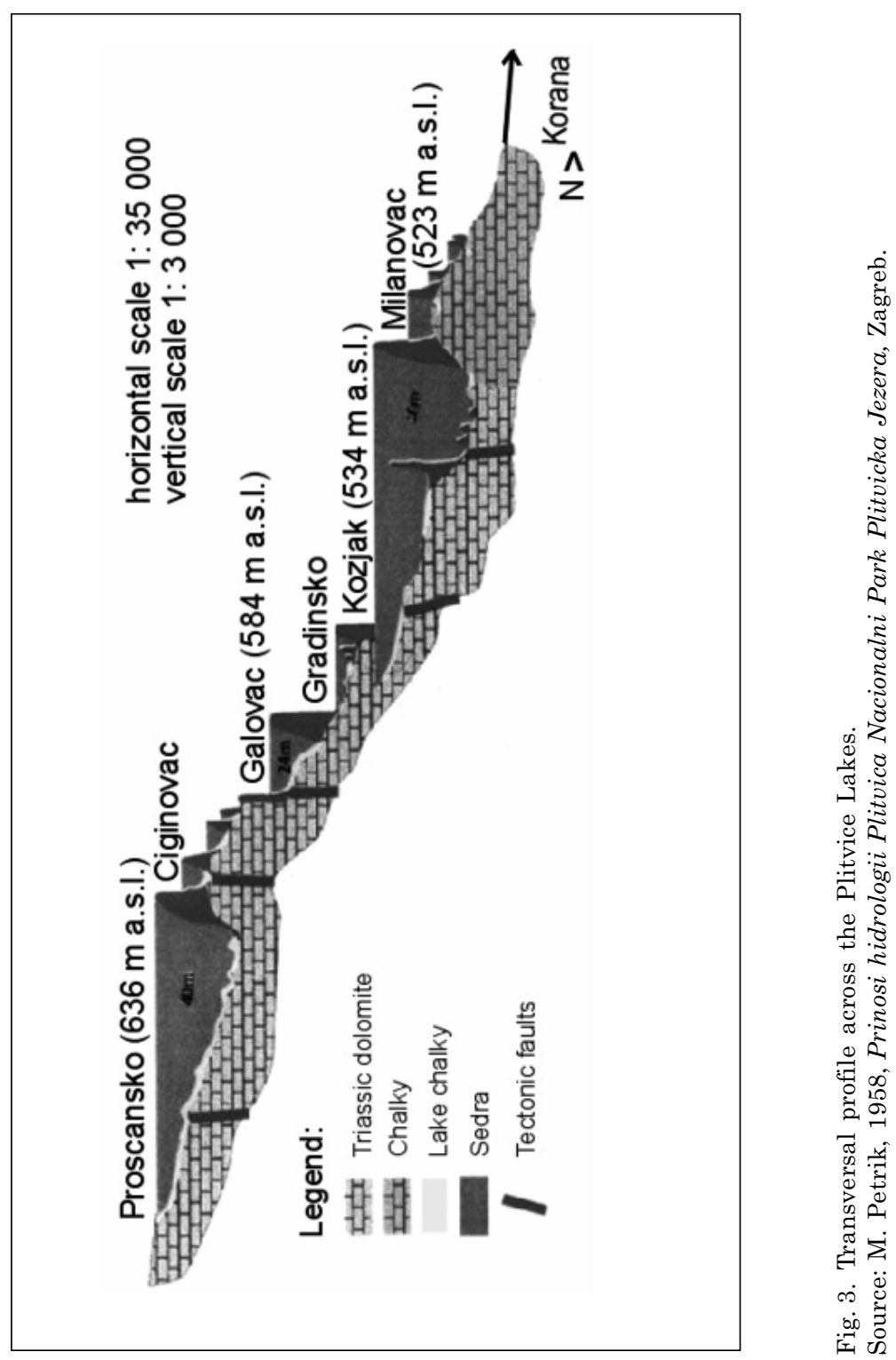


The greatest changes occurred in the southern (inhabited) part of the region. In the valley of the White River (in the southern part of the region) alone there were eight to nine lakes. Furthermore, the floating of timber caused mechanical damage to the young and not yet solidified barriers. Tufa was also used as building material with isolating properties; due to that some barriers have been lowered by a few metres (Franić, 1910). The strongest interference of humans occurred in the southern part of the drainage basin, where the settlements Babin Potok and Plitvički Ljeskovac were founded.

The origins of the Plitvice Lakes are therefore complex. Both tectonic movements and the formation of the travertine barriers contributed to their creation. Crustal movements caused the formation of several fissures and led to the lowering of the Korana riverbed. It is certain that picturesque cascades existed in its riverbed at that time. Just the formation of tufa in the riverbed would not cause its division into the lake basins. At present, tufa is being created also in other rivers in Croatia, such as Zrmanja, Krka, Una, Mrežnica; it forms, however, only "rock islets" in their riverbeds, without dividing them into smaller reservoirs.

To describe the origins of the Plitvice Lakes the term "tectonic-barrier lakes" has been suggested. The simultaneous occurrence of the tectonic faults and of the travertine built on them made possible the creation of the sequence of the Plitvice lakes. As a result of the division of the Korana riverbed by barriers, accumulation of the water occurred and, consequently, the water flooded in the bottom of the valley. This mechanism is identical with that occurring during the creation of the dam lakes by humans. In this case tufa plays the role of a natural barrier. As it was mentioned at the beginning, the Plitvice Lakes, situated on impermeable dolomite, in the upper part of the park, are larger than the lakes situated in the northern part, which is built of limestone. A different geological structure causes a different kind of resistance to water erosion. Impermeable dolomite from the Triassic create wide, open valleys, since water on their bottom can flood. As many as 12 out of 16 lake basins were formed in the dolomite rocks: Prošćansko, Ciginovac, Okrugljak, Batinovac, Malo, Veliko, Vir, Galovac, Milino, Gradinsko, Burget and Kozjak. The surface of the largest of them, Kozjak, is equal to 76.64 hectares. The limestone rock, on the other hand, is permeable to water, which makes the accumulation of water impossible without a watertight layer of, for instance, mud. In the narrow canyon of the Korana River only four lakes were created: Milanovac, Gavanovac, Kaluderovac and Novakovića Brod, of which Lake Milanovac is the largest (2.92 hectares). A common feature of all the lakes is the closure of their basins from the north by a barrier formed by a biogenic rock.

The process described above continues. New underwater barriers are being created, which results in the formation of a complex lake system. Currently in the valley of the Korana River, below the last lake of the system, Novakovica Brod, new lakes are being formed, which is an evidence of the existence and growth of the underwater barriers. 


\section{REFERENCES}

Bajkiewicz-Grabowska E., Mikulski Z., 1996, Hydrologia ogólna [General Hydrology; in Polish], PWN, Warszawa.

Franić D., 1910, Lijepoti $i$ slavi Hrvatske! [Beauties and Glories of Croatia!; in Croatian], Školjska knižnica, Zagreb.

Klimaszewski M., 2003, Geomorfologia [Geomorphology; in Polish], PWN, Warszawa.

Petrik M., 1958, Prinosi hidrologiji Plitvica, Nacionalni park Plitvička jezera [National Park Plitvice Lakes; in Croatian], Zagreb.

Pevalek I., 1958, Biodinamika Plitvičkih jezera i njena zaštita [Biodynamics of the Plitvice Lakes and Their Protection; in Croatian], in: Nacionalni park Plitvička jezera [National Park Plitvice Lakes; in Croatian], Zagreb.

Polšak A., 1974, Geološki aspekt zaštite Plitvičkih jezera [Geological Aspect of the Protection of the Plitvice Lakes; in Croatian], in: Plitvička jezera - Čovjek i priroda [Plitvice Lakes - Man and Nature; in Croatian], Nacionalni park Plitvička jezera, Zagreb.

English translation: Matgorzata Mikulska 